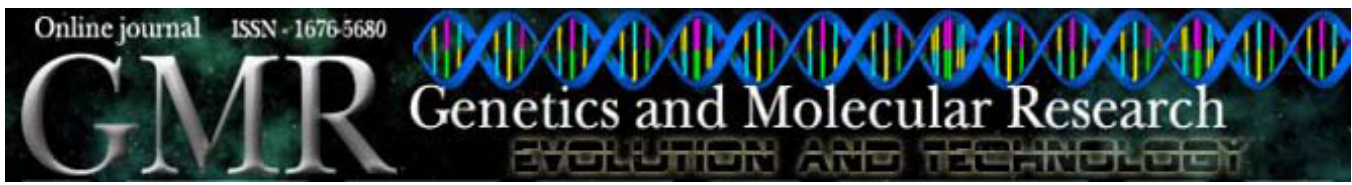

Short Communication

\title{
Differential expression of genes in resistant versus susceptible Gyr $x$ Holstein cattle challenged with the tick Rhipicephalus (Boophilus) microplus
}

C.S. Nascimento ${ }^{1}$, M.A. Machado ${ }^{2}$, S.E.F. Guimarães ${ }^{1}$, M.F.M. Guimarães ${ }^{2}$, J.O. Peixoto ${ }^{1}$, J. Furlong ${ }^{2}$, M.C.A. Prata ${ }^{2}$, R.S. Verneque ${ }^{2}$, R.L. Teodoro ${ }^{2}$ and P.S. Lopes ${ }^{1}$

${ }^{1}$ Departamento de Zootecnia, Universidade Federal de Viçosa, Campus Universitário, Viçosa, MG, Brasil

${ }^{2}$ Embrapa Gado de Leite, Juiz de Fora, MG, Brasil

Corresponding author: M.A. Machado

E-mail: machado@cnpgl.embrapa.br

Genet. Mol. Res. 9 (4): 1974-1979 (2010)

Received May 13, 2010

Accepted July 18, 2010

Published October 5, 2010

DOI 10.4238/vol9-4gmr905

ABSTRACT. The bovine tick Rhipicephalus (Boophilus) microplus causes major losses in cattle production systems in tropical regions. Bos indicus breeds are more resistant to ticks than B. taurus breeds. Resistance genes could be an alternative to control this parasite. We examined the pattern of gene expression of three calcium-bindingprotein genes: translationally controlled tumor protein 1 (TPT1), allergen Bos d3 (S100A7), calcium channel protein transient receptor potential vanilloid 6 (TRPV6), and the cysteine proteinase inhibitor gene (CST6). These genes were selected from cDNA libraries prepared from skin biopsies taken from resistant and susceptible Gyr x Holstein $\mathrm{F}_{2}$ animals. These biopsies were also used to study the expression level of these genes through real-time PCR analysis. The relative expression levels of the S100A7, TPT1, TRPV6, and CST6 genes were 2.01 $\pm 0.6,1.32$ 
$\pm 0.9,1.53 \pm 1.2$, and $2.03 \pm 0.7$ times higher in the susceptible group, respectively. Skin lesion tissue from the susceptible animals showed significantly more mRNA transcripts of these genes in comparison with the resistant animals $(\mathrm{P}=0.001)$. However, this hypersensitivity does not seem to protect the susceptible animals against tick infestation.

Key words: qRT-PCR; Tick resistance; S100A7; TPT1; TRPV6; CST6

Genetic resistance to the bovine tick Rhipicephalus (Boophilus) microplus is one alternative to reduce the costs related to the control of this parasite in tropical regions. The development of new control methods is of great importance for cattle production systems. In general, Bos indicus animals are more resistant to parasitic diseases than B. taurus (Villares, 1941; Utech et al., 1978). The co-existence of Zebu animals with the tick $R$. microplus over the centuries seems to have conferred greater resistance to these animals compared to Taurine animals. So far, little is known about the genetic mechanisms involved in the genetic resistance of Zebu animals to ticks. However, studies regarding this genetic resistance may contribute to the biological control of ticks, since the use of resistant animals is one of the most effective solutions to control this parasite. Genetic resistance can contribute to decrease tick infestation, costs with medications, personnel, mortality, production losses, and can help reduce environmental pollution and intoxication of the animals due to the use of acaricides.

Molecules released by the tick $R$. microplus during attachment and feeding of larvae on the host stimulate innate and acquired immune responses. The ability of the host to respond to these molecules will result in different levels of resistance. The tick counterattacks the host response with immunosuppressive molecules present in its saliva. The saliva of $R$. microplus contains substances that act on T lymphocytes, macrophages, neutrophils, and natural defense cells, and influences the immunoglobulin classes produced in response to the tick antigen (Bobek and Levine, 1992).

In previous experiments, we used expressed sequence tags to analyze transcripts from two cDNA skin libraries in $\mathrm{F}_{2}$ cattle infested with the tick $R$. (Boophilus) microplus. Preliminary results indicated gene expression differences between the resistant and susceptible animals in relation to the allergen Bos d3 (S100A7), translationally controlled tumor protein 1 (TPT1), calcium channel protein transient receptor potential vanilloid 6 (TRPV6), and the cysteine proteinase inhibitor gene (CST6) (Nascimento CS, Machado MA and Guimarães SEF, unpublished results). In this study, we conducted further research, using real-time polymerase chain reaction (qRT-PCR), to validate the differential expression of these genes.

The animals used in this study belonged to an $\mathrm{F}_{2}$ population originated from crossing $\mathrm{F}_{1}$ animals ( $1 / 2$ Holstein: $1 / 2$ Gyr). Based on the results of previously performed genetic evaluations (Teodoro et al., 2006), animals with extreme breeding values for tick resistance/susceptibility were selected for the experimental groups. Six tick-resistant and six tick-susceptible $\mathrm{F}_{2}$ animals were selected based on their breeding value for sample collection. Skin biopsies were obtained from the lesion area caused by the ticks in susceptible and resistant animals after artificial infestation.

Two pools were prepared for the extraction of total RNA, one consisting of skin biopsies from resistant animals and the other from susceptible animals. The biopsies were removed from RNAlater (Ambion, Applied Biosystems, Forter City, CA, USA) solution and were sliced into smaller pieces. Total RNA was extracted using the RNeasy ${ }^{\circledR}$ Midi kit (Qiagen, Valencia, CA, USA) according to manufacturer instructions. A DNase step (RNase-free DNase I, Invitrogen Life Technologies, Carlsbad, CA, USA) 
was performed on the total RNA to remove genomic DNA. The quality of isolated RNA was determined spectrophotometrically $\left(\mathrm{A}_{260}: \mathrm{A}_{280}\right)$ and its integrity was verified by $1.2 \%(\mathrm{w} / \mathrm{v})$ agarose gel electrophoresis with ethidium bromide staining. RNA samples were stored at $-70^{\circ} \mathrm{C}$ until qRT-PCR analysis.

Primer sequences and amplicon length can be viewed in Table 1. All primer sequences used for the amplification of the S100A7, TPT1, TRPV6, and CST6 genes and also for the endogenous control glyceraldehyde-3-phosphate dehydrogenase (GAPDH) gene were designed with the PrimerQuest program, provided by Integrated DNA Technologies, Inc. (Coralville, IA, USA). The SuperScript III First-Strand Synthesis SuperMix kit (Invitrogen) was used to generate the first cDNA strand from total RNA. cDNA was synthesized in a $20-\mu \mathrm{L}$ volume using $1 \mu \mathrm{g}$ total RNA. To confirm the absence of residual genomic DNA contamination, one sample was incubated without reverse transcriptase (negative control).

\begin{tabular}{|c|c|c|c|}
\hline Gene & Primer sequence $\left(5^{\prime}-3^{\prime}\right)$ & Amplicon size (bp) & Accession number ${ }^{1}$ \\
\hline S100A7 & $\begin{array}{l}\text { F: TCA GCT TGA GCA GGC CAT TAC AGA } \\
\text { R: ACA GGC ACT GAC GAA GTT GAG GAA }\end{array}$ & 130 & XM_870600.3 \\
\hline TPT1 & $\begin{array}{l}\text { F: GGG CTG CAG AAC AAA TCA AGC ACA } \\
\text { R: ACA CCA TCC TCA CGG TAG TCC AAT }\end{array}$ & 118 & XM_001254326.1 \\
\hline TRPV6 & $\begin{array}{l}\text { F: ATC ATC GCT GCT TTG CTC ATG CTC } \\
\text { R: AAC GTG GCA GCT TCT TCT CTA GCA }\end{array}$ & 142 & XM_866519.2 \\
\hline GAPDH & $\begin{array}{l}\text { F: GGC GTG AAC CAC GAG AAG TAT AA } \\
\text { R: CCC TCC ACG ATG CCA AAG T }\end{array}$ & 99 & NM_001034034.1 \\
\hline CST6 & $\begin{array}{l}\text { F: AGA AGC TGC GCT GTG ACT TTG AGA } \\
\text { R: ACA GGG ACA CAC AGT CGT GCT TTA }\end{array}$ & 84 & NM_001012764.1 \\
\hline
\end{tabular}

${ }^{1}$ http://www.ncbi.nlm.nih.gov/sites/entrez.

Before qRT-PCR, primer concentrations and cDNA quantity that provided the best efficiency of PCR for both target genes and endogenous control were established. Serial cDNA dilution curves were generated to calculate the amplification efficiency for all genes. A graph of threshold cycle $(\mathrm{Ct})$ versus $\log 10$ relative copy number of the sample from a dilution series was produced. The slope of the curve was used to determine the amplification efficiency (Pfaffl, 2001), in which efficiency $=10^{(-1 / \text { slope })}$. The amount of $100 \mathrm{ng}$ cDNA and the primer concentration of $400 \mathrm{nM}$ were standardized for the amplification of all genes.

qRT-PCR were performed using the SYBR ${ }^{\circledR}$ Green I System (Bio-Rad, Hercules, CA, USA) for detection of PCR products and were carried out in the SDS ABI PRISM 7300 thermocycler (Applied Biosystems, Foster City, CA, USA). mRNA levels were normalized against the cattle GAPDH gene as endogenous control and compared between resistant and susceptible animals. Reactions for the endogenous control and target genes were carried out in duplicate. Each reaction mixture contained $12.5 \mu \mathrm{L} 2 \mathrm{X}$ SYBR ${ }^{\circledR}$ Green Supermix, $400 \mathrm{nM}$ of each primer, and $100 \mathrm{ng}$ cDNA in a final volume of $25 \mu \mathrm{L}$. The amplification conditions included an initial denaturation at $95^{\circ} \mathrm{C}$ for $3 \mathrm{~min}$, followed by 40 cycles of denaturation at $95^{\circ} \mathrm{C}$ for $15 \mathrm{~s}$ and annealing and extension at $60^{\circ} \mathrm{C}$ for $60 \mathrm{~s}$ (for all primers). Amplicons were free from DNA contamination as judged by a lack of signal from non-reverse transcribed RNA with all primer sets. A mean $\mathrm{Ct}$ was established for the target genes and reference gene and $\Delta \mathrm{Ct}$ values were calculated $[\Delta \mathrm{Ct}=\mathrm{Ct}$ (target gene) - $\mathrm{Ct}(\mathrm{GAPDH})]$. Individual reactions were performed for each gene in a 96-well plate. The relative expression analysis of the target gene was performed using the REST software (Pfaffl et al., 2002) for group-wise comparison in real-time PCR. Randomization data and analysis of qRT-PCR are shown in Table 2. 
Table 2. Output of randomization test and analysis of target genes S100A7, TPT1, TRPV6, and CST6 and the reference gene GAPDH in skin tissue from cattle resistant (R) and susceptible (S) to ticks.

\begin{tabular}{lccc}
\hline Gene & Threshold cycle & Standard deviation & Coefficient of variation (\%) \\
\hline S100A7 (R) & 17.7 & 0.43 & 3.43 \\
S100A7 (S) & 16.3 & 0.06 & 0.56 \\
TPT1 (R) & 27.1 & 0.10 & 0.52 \\
TPT1 (S) & 25.7 & 0.31 & 1.73 \\
TRPV6 (R) & 28.3 & 0.18 & 0.88 \\
TRPV6 (S) & 28.0 & 0.15 & 0.73 \\
CST6 (R) & 22.7 & 0.02 & 0.12 \\
CST6 (S) & 21.2 & 0.13 & 0.90 \\
GAPDH (R) & 21.9 & 0.17 & 1.06 \\
GAPDH (S) & 22.3 & 0.03 & 0.19 \\
\hline
\end{tabular}

Ct values in the two groups ranged from 16.3 to 28.3 for target genes and from 21.9 to 22.3 for GAPDH. The lower $\mathrm{Ct}$ value for S100A7 indicates that this gene reaches the detection threshold with less amplification cycles than GAPDH, suggesting that it is more abundant in the skin. On the other hand, the TPT1 and TRPV6 genes showed higher $\mathrm{Ct}$ values than GAPDH indicating that these genes are less abundant. The coefficient of variation ranged from 0.52 to 3.43 for target genes and from 0.19 to 1.06 for GAPDH across all groups.

The expression levels of target genes showed overexpression of S100A7, TPT1, TRPV6, and CST6 in skin biopsies from the susceptible group. S100A7 was classified as the most expressed gene, followed by TRPV6 and TPT1. The expression ratios of all genes in the resistant and susceptible animals are summarized in Figure 1.

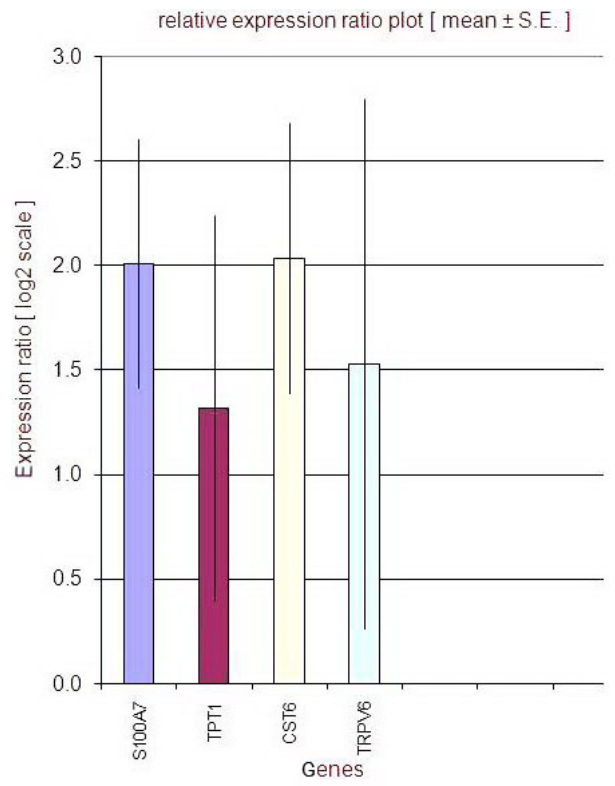

Figure 1. Relative expression of S100A7 (2.01 \pm 0.6$)$, TPT1 (1.32 \pm 0.9$)$, TRPV6 (1.53 \pm 1.2$)$, and CST6 (2.03 \pm 0.7 ) genes in skin samples from resistant and susceptible animals. Fold change (y-axis) represents the relative expression of the S100A7, TPT1, TRPV6, and CST6 genes in comparison to the resistant group, normalized by GAPDH reference gene expression. Significantly differential expression was shown by all genes $(\mathrm{P}<0.001)$. 
S100A7 gene is involved in calcium-dependent signal transduction and is related to cellular changes in response to extracellular stimuli. In the present study, expression of the S100A7 gene was higher in skin lesions from the susceptible group, $2.01 \pm 0.6$ times. Our results show that the amplified products of the S100A7 gene started to be detected around cycle 17 before the other genes and even before the endogenous control (Table 2), suggesting that this gene is overexpressed in this tissue. We hypothesize that the S100A7 gene can promote an increase in leukocyte recruitment to the affected region and thus contribute to pro-inflammatory activity in susceptible animals.

Functional studies have shown that the TPT1 gene encodes a calcium-binding protein that is induced in the presence of various intracellular stimuli. Our results showed a higher expression of the histamine-releasing protein (TPT1/HRF) in skin lesions of susceptible animals, an increase of $1.32 \pm 0.9$-fold in relation to resistant animals. One possible explanation for this finding may be the presence of antihistamine molecules or histamine-binding proteins in the tick saliva that compete for histamine receptors, with a consequent reduction in the inflammatory response of the host to the tick bite (Paesen et al., 2000).

Similarly, our results showed a $1.53 \pm 1.2$-fold increase in the expression of the TRPV6 gene in skin lesions of susceptible animals. The TRPV6 gene, recently renamed epithelial calcium channel 2 (EcaC2), encodes a transmembrane protein responsible for the absorption of calcium (Montell et al., 2002). The differential expression of TRPV6 in skin lesions of animals challenged with $R$. microplus agrees with the pattern expected for inflamed tissues, since the stimulus caused by the bite and the action of various substances present in the tick's saliva induce the continuous migration of neutrophils and other defense cells to the affected region, thus characterizing a pro-inflammatory state. Therefore, our findings agree with results reported in the literature, demonstrating the presence of a larger number of defense cells in inflamed tissues and consequently greater calcium-mediated cell communication (Heiner et al., 2003). Despite the significant difference between mean expressions of the TRPV6 gene, the standard error was relatively high. Since the results were obtained from a pool of skin biopsies of six animals, the broad variation in standard error could be the result of the pool composition of tissues from animals exhibiting different levels of TRPV6 gene expression.

Relative quantification by real-time PCR analysis revealed a 2.03-fold increase in the expression of the CST6 gene in skin biopsies of susceptible animals compared to resistant animals. Kotsyfakis et al. (2006) described a cystatin, sialostatin L, in saliva that affects the proteolytic activity at inflammation sites, exhibiting anti-inflammatory activity, and inhibiting the proliferation of host cytotoxic $\mathrm{T}$ lymphocytes, thus contributing to the feeding success of the parasite. Using serial analysis of gene expression in human keratinocyte cultures, Jansen et al. (2001) found high levels of expression of genes possibly involved in host protection and defense such as proteinase inhibitors and antimicrobial proteins. We, therefore, suggest that positive regulation of the host cystatin 6 gene transcripts may favor attachment of the tick in susceptible animals by indirectly inhibiting the action of cytotoxic $\mathrm{T}$ lymphocytes and, consequently, the production of host defense cytokines. Cystatin 6 probably acts on proteases, controlling the exaggerated proteolysis of proteins during regeneration of the epidermis and contributes to the feeding success of the parasite.

In general, our results show the existence of differential expression of S100A7, TPT1, TRPV6, and CST6 genes in skin biopsies of susceptible animals compared to resistant animals regarding $R$. microplus infestation. This is the first study showing the differential expression 
of genes encoding calcium-binding proteins and a calcium channel protein in cattle. Little is known how these genes participate in the mechanism of the host's response to the parasite. These results may explain the skin hypersensitivity of susceptible animals, but this hypersensitivity does not seem to be effective in protecting susceptible animals against tick infestation. Other genes could be involved in the host defense mechanism. In addition, parasite-host interactions involve a complex network of gene activation mechanisms.

The identification of new genes and host antigens involved in the mechanism of resistance/susceptibility to R. microplus is a promising approach that could help to develop new strategies to control this parasite in cattle.

\title{
ACKNOWLEDGMENTS
}

\author{
Research supported by FINEP, CNPq, CAPES, EMBRAPA, and FAPEMIG.
}

\section{REFERENCES}

Bobek LA and Levine MJ (1992). Cystatins-inhibitors of cysteine proteinases. Crit. Rev. Oral Biol. Med. 3: 307-332.

Heiner I, Eisfeld J and Luckhoff A (2003). Role and regulation of TRP channels in neutrophil granulocytes. Cell Calcium 33: 533-540.

Jansen BJ, van Ruissen F, de Jongh G, Zeeuwen PL, et al. (2001). Serial analysis of gene expression in differentiated cultures of human epidermal keratinocytes. J. Invest. Dermatol. 116: 12-22.

Kotsyfakis M, Sá-Nunes A, Francischetti IM, Mather TN, et al. (2006). Antiinflammatory and immunosuppressive activity of sialostatin L, a salivary cystatin from the tick Ixodes scapularis. J. Biol. Chem. 281: 26298-26307.

Montell C, Birnbaumer L and Flockerzi V (2002). The TRP channels, a remarkably functional family. Cell 108: 595-598.

Paesen GC, Adams PL, Nuttall PA and Stuart DL (2000). Tick histamine-binding proteins: lipocalins with a second binding cavity. Biochim. Biophys. Acta 1482: 92-101.

Pfaffl MW (2001). A new mathematical model for relative quantification in real-time RT-PCR. Nucleic Acids Res. 29: e45.

Pfaffl MW, Horgan GW and Dempfle L (2002). Relative expression software tool (REST) for group-wise comparison and statistical analysis of relative expression results in real-time PCR. Nucleic Acids Res. 30: e36.

Teodoro RL, Pires MFA, Furlong J, Prata MCA, et al (2006). Estimativas de Parâmetros Genéticos e Fenotípicos para a Resistência a Carrapatos e Bernes em uma População Experimental F2 Holandês x Gir. In: Anais da 43a. Reunião Anual da Sociedade Brasileira de Zootecnia (SBZ, ed.), João Pessoa. (CD ROM).

Utech KBW, Seifert GW and Wharton RH (1978). Breeding Australian lllawarra Shorthorn cattle for resistance to Boophilus microplus. I. Factors affecting resistance. Aust. J. Agric. Res. 29: 411-422.

Villares JB (1941). Climatologia Zootécnica. III. Contribuição ao Estudo de Resistência e Susceptibilidade Genética dos Bovinos ao Boophilus microplus. In: Boletim da Indústria Animal. Nova Série, São Paulo, 4: 60-86. 